$$
C_{1}^{\prime}=\frac{D}{k}-C_{3}
$$

此の二式より $C_{1}$ 及び $C_{3}$ 老計算し得。從つて本衡恒數 $K$ ○亦 (2) より計算し得。 計算は第 2 圖に就きてなせり。其の結果は第 2 表に示すが如し。

第 2 表

$フ ェ ノ ー ル$ 重合恒數の計算

\begin{tabular}{c|c|c|c|c|c|c}
\hline$C_{0}$ & $D$ & $\frac{D}{k}$ & $C_{3}$ & $C_{1}$ & $K$ \\
\hline 0.4000 & 0.673 & 0.3618 & 0.0191 & 0.3427 & 0.47 \\
0.3000 & 0.596 & 0.3204 & 0.0148 & 0.3056 & 0.52 & 0.46 \\
0.0000 & 0.519 & 0.2814 & 0.0093 & 0.2721 & 0.53 \\
0.2500 & 0.441 & 0.2371 & 0.0065 & 0.2306 & 0.51 \\
0.2000 & 0.359 & 0.1930 & 0.0035 & 0.1895 & & 0.51 \\
\hline
\end{tabular}

第 2 圆に於て $C_{o}=0.2$ 以下の稀薄なる部分にては、實測點は㱠どRaoult の直線と 一致せるを以て此の部芀の $K$ の計算は避りたり。元來水點降下の寒匳は誤差大なる

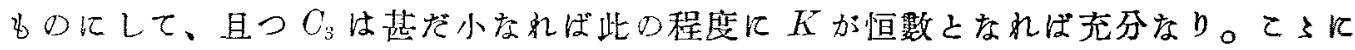
於て吾人の假定の正しき事老證明好り。

結 詥

水點降下の研究上りフ

$$
3 \mathrm{C}_{6} \mathrm{H}_{6} \mathrm{OH} \longrightarrow\left(\mathrm{C}_{6} \mathrm{H}_{6} \mathrm{O}\right)_{3}
$$

なる化學本衡の成立せるを知れり。而して零度比於りる重合恆數は

$$
\frac{C_{3}}{C_{1}^{3}}=K=0.50
$$

なり。

東京帝國大學理學部 化學教室 物理化學研究室に於て。

\title{
水よベンゼンとの間に於けるフェノールの分配に 對する中性監類の影響に就て
}

适藤 完 太 郎

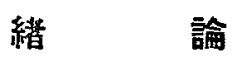

監析作用(Salting out，Aussalzen)之呼ばるる現象は既に可なり古くより知られ、睍 
際よく應用さるるるのなり。一般に非電解質 (Non-electrolyte) 索水に溶解せしむる場 合に於て水に中性監類を加ふる時は㱠ど例外なく其の非電解質の溶解度は減少す。

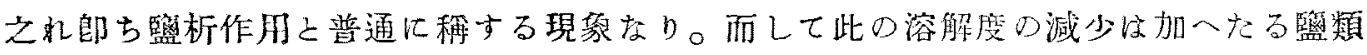
の漂度が大なれば大なる程大なり。

此の定量的研究法多くの人に依りてなされしが其の最初の人は Setschenow [Mem. de l'Acal. imp. des sc. de St. Petersburg (7) 22, No. 6 (1875); 34, No. 3 (1ss6); 35, No. 7 (1857); Zeitschr.f. phys. Chem. 4, 117 (18s9); Ann. de Chim. et phys. (6) 25, 226 (1892)]なり。

Setschenow は炭酸死斯につきて研究せしが、次の式を得たり。

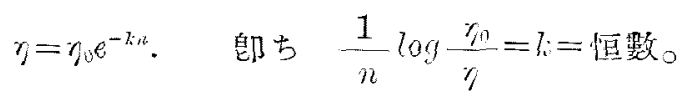

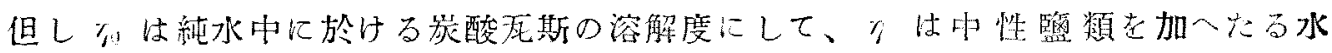

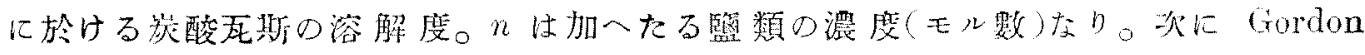

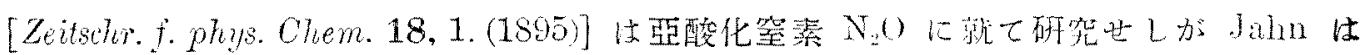
此のGordon の測定より次の式を出世口。即去

$$
\frac{1}{n^{\frac{3}{3}}} \frac{x_{0}-\eta}{x_{0}}=\text { 恒數。 }
$$

併し乍ら、G.Geffeken [Zeitschrf.f.phys.Chem.49, 257 (1904)] は精密なる實䲆によ りJahnの出したる式度不適合なる事を發表せり。

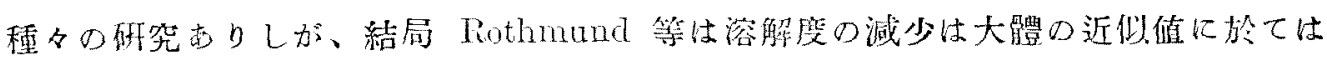
加入たる物领口濃度に比例する事圭認心、

$$
\frac{1}{n} \frac{x_{n}-x_{1}}{x_{0}}=h .
$$

なる量を“ die molekulare bzw. äguivalente Löslichkeitserniedrigung”上名附けた

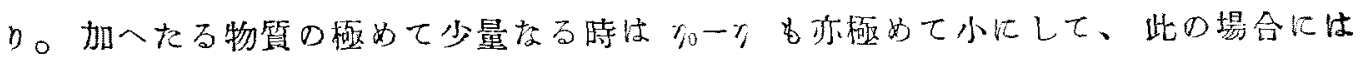
明に Setschenow の式と一致す。

近年に於ては Thorne (Journ. Chem.Soc.119,1921)がエーテルの水に於る溶解度に

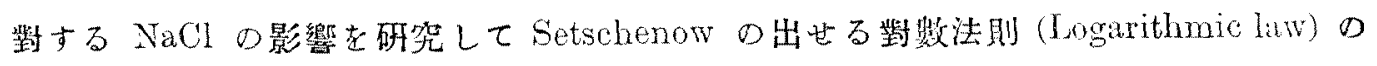
邀合する事を發表せり。

フェノールの水に於ける溶解度に對する硫酸カリウムの影䇣に就きては Rothmund

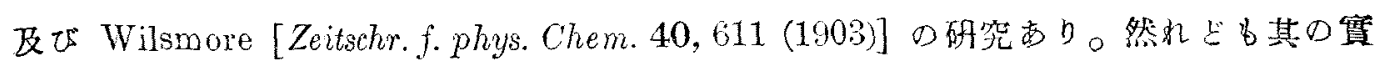
羷少きためかあまりよを結果を與へざりき。 
熱力學より出す種々の法則は貫際上稀溥溶液のみ合理的の取报ひをなし得るるのな

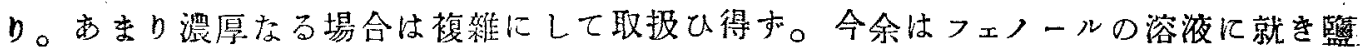
析作用を研究せ九とす。故にフェノールの稀潮溶液に就きて Aussalzen を研究する必

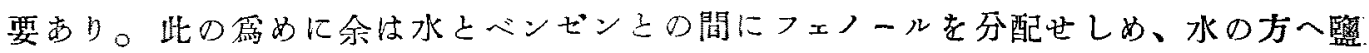
類を加へて其の影摡を研究せり。蓋し分配に就ては任意の稀薄溶液につ研究し得 る便利古ればなり。

\section{䔈驗 の 部}

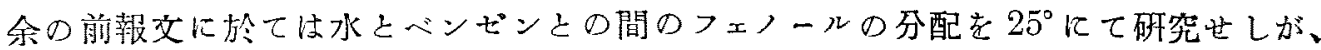
今度は水の代りに種々の哭機中性監頻の水溶液を使用し、之とべンゼンとの間に於け

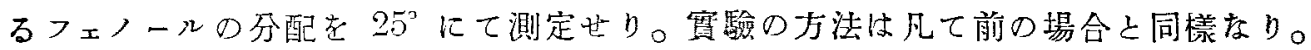

使用世る監類は次の如し。

$\begin{array}{lllll}\mathrm{NaCl}, & \mathrm{NaBr} . & \mathrm{NaNO}_{3}, & \mathrm{Na}_{2} \mathrm{SO}_{4}, & \\ \mathrm{KCl}, & \mathrm{KBr}, & \mathrm{KNO}_{3}, & \mathrm{~K}_{2} \mathrm{SO}_{4}, & \\ \text { LiBr., } & \mathrm{LiNO}_{3}, & \mathrm{Ca}\left(\mathrm{NO}_{3}\right)_{2}, & \mathrm{Sr}\left(\mathrm{NO}_{3}\right)_{2}, & \\ \mathrm{SrCl}, & \mathrm{BaCl}_{2}, & \mathrm{Ba}\left(\mathrm{NO}_{3}\right)_{2}, & \mathrm{MgSO}_{4} & \text { LiCl. }\end{array}$

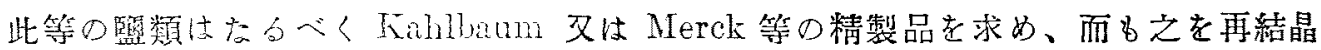
法に依りて精製せるbのを用ひたり。

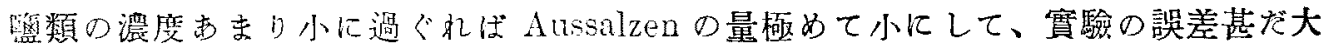

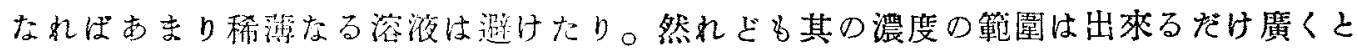
れり。

實羷の結果は次の如し。

但し鼬度は凡て一立中のモル數を以て表はし、Bはベンビン層中のフェノールの漂 度、Cは監類の水溶液中に於けるフェノールの濃度をあらはし、Sは用ひたる監類の 濃度とす。

（1） $\mathrm{NaCl}$ の場合

\begin{tabular}{|cc|cc|cc|}
\hline \multicolumn{2}{|c|}{$\mathrm{S}=2$ N } & \multicolumn{2}{|c|}{$\mathrm{S}=1$} & \multicolumn{2}{|c|}{$\mathrm{S}=0.5$} \\
$\mathrm{~B}$ & $\mathrm{C}$ & $\mathrm{B}$ & $\mathrm{C}$ & $\mathrm{B}$ & $\mathrm{C}$ \\
1.5142 & 0.1282 & 1.4573 & 0.1851 & 1.4180 & 0.2244 \\
0.7590 & 0.0912 & 0.7187 & 0.1316 & 0.6945 & 0.1557 \\
0.4383 & 0.0656 & 0.4126 & 0.0913 & 0.3948 & 0.1091 \\
0.2052 & 0.0379 & 0.1913 & 0.0518 & 0.1839 & 0.0593 \\
\hline
\end{tabular}

（2） $\mathrm{NaBr}$ の場合

\begin{tabular}{|cc|cc|cc|}
\hline \multicolumn{2}{|c|}{$\mathrm{S}=2.589$} & \multicolumn{2}{|c|}{$\mathrm{S}=1.2945$} & \multicolumn{2}{c|}{$\mathrm{S}=0.6473$} \\
$\mathrm{~B}$ & $\mathrm{C}$ & $\mathrm{B}$ & $\mathrm{C}$ & $\mathrm{B}$ & $\mathrm{C}$ \\
0.9316 & 0.0883 & 0.8842 & 0.1357 & 0.8513 & 0.1686 \\
0.6444 & 0.0738 & 0.6077 & 0.1106 & 0.5825 & 0.1357 \\
0.4186 & 0.0562 & 0.3916 & 0.0832 & 0.3734 & 0.1014 \\
& & 0.1937 & 0.0498 & & \\
\hline
\end{tabular}


(3) $\mathrm{NaNO}_{3}$ の場合

\begin{tabular}{|cc|cc|cc|cc|cc|}
\hline \multicolumn{2}{|c|}{$\mathrm{S}=3.0$} & \multicolumn{2}{|c|}{$\mathrm{S}=2.0$} & \multicolumn{2}{c|}{$\mathrm{S}=1.0$} & \multicolumn{2}{c|}{$\mathrm{S}=0.5$} & \multicolumn{2}{c|}{$\mathrm{S}=0.25$} \\
$\mathbf{B}$ & $\mathrm{C}$ & $\mathbf{B}$ & $\mathrm{C}$ & $\mathrm{B}$ & $\mathrm{C}$ & $\mathrm{B}$ & $\mathrm{C}$ & $\mathrm{B}$ & $\mathrm{C}$ \\
1.1931 & 0.1159 & 1.1583 & 0.1507 & 1.0911 & 0.1902 & 1.0697 & 0.2117 & 1.0559 & 0.2255 \\
0.9045 & 0.1023 & 0.8756 & 0.1313 & 0.8205 & 0.1651 & 0.8025 & 0.1830 & 0.7907 & 0.1949 \\
0.6256 & 0.0827 & 0.6029 & 0.1054 & 0.5757 & 0.1326 & 0.5614 & 0.1469 & 0.5535 & 0.1547 \\
0.2872 & 0.0484 & 0.2757 & 0.0599 & 0.2604 & 0.0752 & 0.2519 & 0.0837 & 0.2437 & 0.0882 \\
0.1399 & 0.0280 & 0.1334 & 0.0344 & 0.1257 & 0.0421 & 0.1225 & 0.0453 & 0.1198 & 0.0481 \\
\hline
\end{tabular}

（4） $\mathrm{Na}_{2} \mathrm{SO}_{4}$ の場合

\begin{tabular}{|cc|cc|cc|cc|}
\hline \multicolumn{2}{|c|}{$\mathrm{S}=1.007$} & \multicolumn{2}{|c|}{$\mathrm{S}=0.5166$} & \multicolumn{2}{|c|}{$\mathrm{S}=0.2583$} & \multicolumn{2}{c|}{$\mathrm{S}=0.1292$} \\
$\mathrm{~B}$ & $\mathrm{C}$ & $\mathrm{B}$ & $\mathrm{C}$ & $\mathrm{B}$ & $\mathrm{C}$ & $\mathrm{B}$ & $\mathrm{C}$ \\
1.3138 & 0.1008 & 1.1605 & 0.1505 & 1.1210 & 0.1901 & 1.0978 & 0.2133 \\
$0.817 \mathrm{~s}$ & 0.0820 & 0.6111 & 0.1071 & 0.5851 & 0.1331 & 0.5698 & 0.1484 \\
0.6493 & 0.0689 & 0.3193 & 0.0884 & 0.3812 & 0.1004 & 0.3705 & 0.1112 \\
0.3419 & 0.0458 & & & 0.1380 & 0.0451 & 0.1342 & 0.0489 \\
\hline
\end{tabular}

(6) $\mathrm{KBr}$ の場合

\begin{tabular}{|c|c|c|c|c|c|}
\hline \multicolumn{2}{|c|}{$S=2.3533$} & \multicolumn{2}{|c|}{$S=1.1766$} & \multicolumn{2}{|c|}{$S=0.5883$} \\
\hline $\mathrm{B}$ & $\mathrm{C}$ & B & $\mathrm{C}$ & $\mathrm{B}$ & $\mathrm{C}$ \\
\hline 0.8331 & 0.1165 & 0.7978 & 0.1518 & 0.8372 & 0.189 \\
\hline 0.5215 & $0.088 \overline{5}$ & 0.4957 & 0.1143 & 0.5726 & 0.1457 \\
\hline \multirow[t]{2}{*}{0.9767} & 0.0568 & 0.2597 & 0.0798 & 0.3667 & 0.1081 \\
\hline & & & & $0.180 \pm$ & 0.0630 \\
\hline
\end{tabular}

(8) $\mathrm{K}_{:} \mathrm{SO}_{4}$ の場合

\begin{tabular}{|cc|cc|}
\hline \multicolumn{2}{|c|}{$S=0.50305$} & \multicolumn{2}{c|}{$S=0.25136$} \\
$\mathrm{~B}$ & $\mathrm{C}$ & $\mathrm{B}$ & $\mathrm{C}$ \\
1.1489 & 0.1622 & 1.2083 & 0.2163 \\
0.6033 & 0.1149 & 0.7396 & 0.1601 \\
0.3951 & 0.0866 & 0.3774 & 0.1743 \\
0.1442 & 0.0389 & 0.1369 & 0.0462 \\
\hline
\end{tabular}

(10) $\mathrm{LiNO}_{3}$ の場合

\begin{tabular}{|cc|cc|cc|}
\hline \multicolumn{2}{|c|}{$\mathrm{S}=1.7688$} & \multicolumn{2}{|c|}{$\mathrm{S}=0.8844$} & \multicolumn{2}{c|}{$\mathrm{S}=0.442 .2$} \\
$\mathrm{~B}$ & $\mathrm{C}$ & $\mathrm{B}$ & $\mathrm{C}$ & $\mathrm{B}$ & $\mathrm{C}$ \\
0.8676 & 0.1523 & 0.8417 & 0.1782 & 0.8277 & 0.1922 \\
0.5704 & 0.1210 & 0.5517 & 0.1397 & 0.5416 & 0.1498 \\
0.3836 & 0.0912 & 0.3018 & 0.0905 & 0.2943 & 0.0980 \\
\hline
\end{tabular}

（5） $\mathrm{KCl}$ の場合

\begin{tabular}{|cc|cc|}
\hline$S=2.099$ & \multicolumn{2}{|c|}{$S=0.9017$} \\
$B$ & $\mathrm{O}$ & $\mathrm{B}$ & $\mathrm{C}$ \\
1.49 .56 & 0.1468 & 1.4399 & 0.2025 \\
0.7445 & 0.1053 & 0.7093 & 0.1420 \\
0.4302 & 0.0771 & 0.4043 & 0.0996 \\
0.2012 & 0.0419 & 0.1887 & 0.0544 \\
\hline
\end{tabular}

（7） $\mathrm{KNO}_{3}$ の場合

\begin{tabular}{|cc|cc|}
\hline \multicolumn{2}{|c|}{$S=2.0007$} & \multicolumn{2}{|c|}{$S=0.9989$} \\
$\mathrm{~B}$ & $\mathrm{C}$ & $\mathrm{B}$ & $\mathrm{C}$ \\
1.4505 & 0.1919 & 1.4127 & 0.2297 \\
0.7159 & 0.1344 & 0.6897 & 0.1606 \\
0.4094 & 0.0945 & 0.3927 & 0.1112 \\
0.1910 & 0.0521 & 0.1828 & 0.0603 \\
\hline
\end{tabular}

(9) $\mathrm{LiBr}$ の場合

\begin{tabular}{|cc|cc|cc|}
\hline \multicolumn{2}{|c|}{$s=1.5284$} & \multicolumn{2}{|c|}{$s=0.7632$} & \multicolumn{2}{c|}{$s=0.3816$} \\
$\mathrm{~B}$ & $\mathrm{C}$ & $\mathrm{E}$ & $\mathrm{C}$ & $\mathrm{B}$ & $\mathrm{C}$ \\
0.8628 & 0.1683 & 0.8422 & 0.1889 & 0.8300 & 0.3011 \\
0.5218 & 0.1259 & 0.3047 & 0.1424 & 0.4978 & 0.1493 \\
0.2426 & 0.0740 & 0.2352 & 0.0814 & 0.2329 & 0.0844 \\
\hline
\end{tabular}

（11） $\mathrm{Ca}\left(\mathrm{NO}_{3}\right)_{2}$ の場合

\begin{tabular}{|cc|cc|cc|}
\hline \multicolumn{2}{|c|}{$\mathrm{S}=1.2917$} & \multicolumn{2}{|c|}{$S=0.8748$} & \multicolumn{2}{|c|}{$S=0.4486$} \\
$\mathrm{~B}$ & $\mathrm{C}$ & $\mathrm{B}$ & $\mathrm{C}$ & $\mathrm{B}$ & $\mathrm{C}$ \\
0.9353 & $0.154 \mathrm{I}$ & 0.9168 & 0.1726 & 0.7695 & 0.1801 \\
0.6926 & 0.1311 & 0.4913 & 0.1187 & 0.4782 & 0.1318 \\
0.3159 & 0.0765 & 0.2576 & 0.0758 & 02492 & 0.0843 \\
\hline
\end{tabular}


（12） $\mathrm{Sr}\left(\mathrm{NO}_{3}\right)_{2}$ の場合

\begin{tabular}{|cc|cc|cc|cc|}
\hline \multicolumn{2}{|c|}{$\mathrm{S}=1.592$} & \multicolumn{2}{|c|}{$\mathrm{S}=0.7959$} & \multicolumn{2}{|c|}{$\mathrm{S}=0.3979$} & \multicolumn{2}{|c|}{$\mathrm{S}=0.199$} \\
$\mathrm{~B}$ & $\mathrm{C}$ & $\mathrm{B}$ & $\mathrm{C}$ & $\mathrm{B}$ & $\mathrm{C}$ & $\mathrm{B}$ & $\mathrm{C}$ \\
0.8294 & 0.1202 & 0.7900 & 0.1596 & 0.7709 & 0.1787 & 0.8207 & 0.1992 \\
0.5188 & 0.0912 & 0.4929 & 0.1171 & 0.4798 & 0.1302 & 0.5600 & 0.1583 \\
0.2735 & 0.0600 & 0.2580 & 0.0755 & 0.2500 & 0.0835 & 0.3578 & 0.1170 \\
& & & & & & 0.1757 & 0.0677 \\
\hline
\end{tabular}

(14) $\mathrm{BaCl}_{2}$ の場合

\begin{tabular}{|cc|cc|cc|}
\hline \multicolumn{2}{c|}{$\mathrm{S}=1.595 \mathrm{~L}$} & \multicolumn{2}{c|}{$\mathrm{S}=0.7975$} & \multicolumn{2}{c|}{$S=0.3988$} \\
$\mathrm{~B}$ & $\mathrm{C}$ & $\mathrm{B}$ & $\mathrm{C}$ & $\mathrm{B}$ & $\mathrm{C}$ \\
0.9697 & 1.0762 & 0.9130 & 0.1289 & 0.8744 & 0.1655 \\
0.6292 & 0.0601 & 0.5895 & 0.0990 & 0.5622 & 0.1271 \\
0.3481 & 0.0434 & 0.3244 & 0.0671 & 0.3066 & 0.0849 \\
\hline
\end{tabular}

（13） $\mathrm{SrCl}_{2}$ の場合

\begin{tabular}{|cc|cc|cc|}
\hline $\mathrm{S}=1.0265$ & \multicolumn{2}{|c|}{$\mathrm{S}=0.5133$} & \multicolumn{2}{|c|}{$\mathrm{S}=0.2566$} \\
$\mathbf{B}$ & $\mathrm{C}$ & $\mathrm{B}$ & $\mathrm{C}$ & $\mathrm{B}$ & $\mathrm{C}$ \\
1.1124 & 0.1166 & 1.0645 & 0.1645 & 1.0345 & 0.1945 \\
0.7403 & 0.0929 & 0.7007 & 0.1325 & 0.6780 & 0.1552 \\
0.3207 & 0.0555 & 0.3013 & 0.0749 & 0.2899 & 0.0863 \\
\hline
\end{tabular}

$\mathrm{Ba}\left(\mathrm{NO}_{3}\right)_{2}$ は溶解度小なれ济 $\mathrm{S}=0.1807$ の場合のみに就きて骨せり。

(16) $\mathrm{MgSO}_{+}$の堏合

\begin{tabular}{|cc|cc|}
\hline \multicolumn{2}{|c|}{$S=0.0985$} & \multicolumn{2}{c|}{$S=0.5468$} \\
$B$ & $\mathrm{C}$ & $\mathrm{B}$ & $\mathrm{C}$ \\
0.9878 & 0.1016 & 0.9448 & 0.1446 \\
0.7348 & 0.0888 & 0.6998 & 0.1238 \\
0.3383 & 0.0541 & 0.3179 & 0.0746 \\
\hline
\end{tabular}

理 論 の 部
(15) $\mathrm{Ba}\left(\mathrm{NO}_{3}\right)_{2}$ の場合

\begin{tabular}{|cc|}
\hline & $\mathrm{S}=0.1807$ \\
$\mathrm{~B}$ & $\mathrm{C}$ \\
0.7624 & 0.1872 \\
0.4717 & 0.1383 \\
0.2465 & 0.0870 \\
\hline
\end{tabular}

(17) $\mathrm{LiCl}$ ○場合

\begin{tabular}{|cc|cc|cc|}
\hline \multicolumn{2}{|c|}{$\mathrm{S}=1.5 \pm 52$} & \multicolumn{2}{|c|}{$\mathrm{S}=0.7726$} & \multicolumn{2}{c|}{$\mathrm{S}=0.3863$} \\
$\mathrm{~B}$ & $\mathrm{C}$ & $\mathrm{B}$ & $\mathrm{C}$ & $\mathrm{B}$ & $\mathrm{C}$ \\
0.9149 & 0.1162 & 0.8757 & 0.1554 & 0.8520 & 0.1791 \\
0.5989 & 0.0954 & 0.5652 & 0.1241 & 0.5130 & 0.1342 \\
0.3255 & 0.0659 & 0.3082 & 0.0833 & 0.2976 & 0.0939 \\
\hline
\end{tabular}

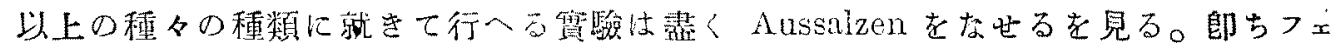

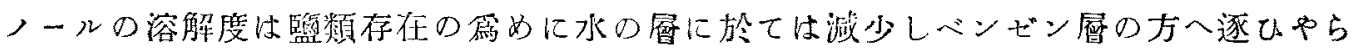
るるを示す。此の事は笚に前揭の表の數字を見たるのみにては明ならざるる若し次に

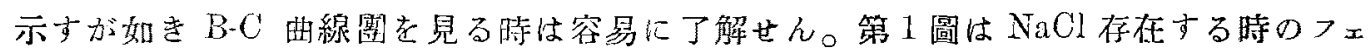

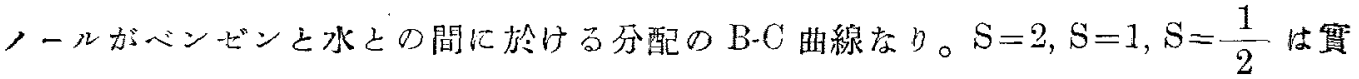

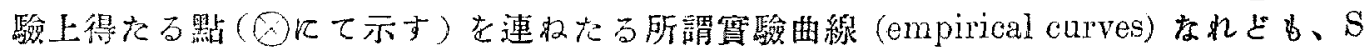
$=0$ 印古 $\mathrm{NaCl}$ の存在せざる埸合は余の前報文に於て得たる理諭上より䚺算せる曲線

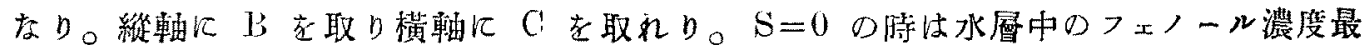
大なる筈なれどる圖は明に最右端の曲線となり。他の談曲線に比して Cの最大なる 事を示す。S の增すにつれて Aussalzen は大となれば曲線は淖次左方へ移る。

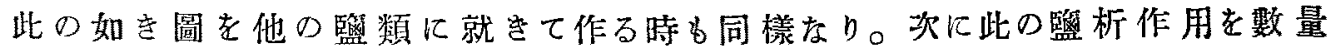


的に研究せん。先づ試みに彼の

Setschenow の出せる對數法則の 適合するや否やを檢せん。

第1圖に於て一つの水平線（例 へばB=1.0)を引き己と $S=0$ 曲線 との交點老 $\mathrm{C}_{0}, \mathrm{~S}=\frac{1}{2}$ 曲線之の 交點を $\mathrm{C}_{\frac{1}{2}}, \mathrm{~S}=1$ とD交點孛 $\mathrm{C}_{1}$, $\mathrm{S}=2$ と口交點走 $\mathrm{C}_{2}$ と世九。然 らば $\mathrm{C}_{0}, \mathrm{C}_{\frac{1}{2}}, \mathrm{C}_{1}, \mathrm{C}_{2}$ は皆同一のへ ンベン相 $(B=1.0)$ 上本衡にする水 溶液相のフェノール竖度表は す。而して $C_{0}$ は前報文に於てW とせる它のと同一にして、S=0の 時なれば、之標準として他の $\mathrm{C}_{\frac{1}{2}}, \mathrm{C}_{1}, \mathrm{C}_{2}$ は如何に減少せりゃを 比較すべをなり。

第 1 圖

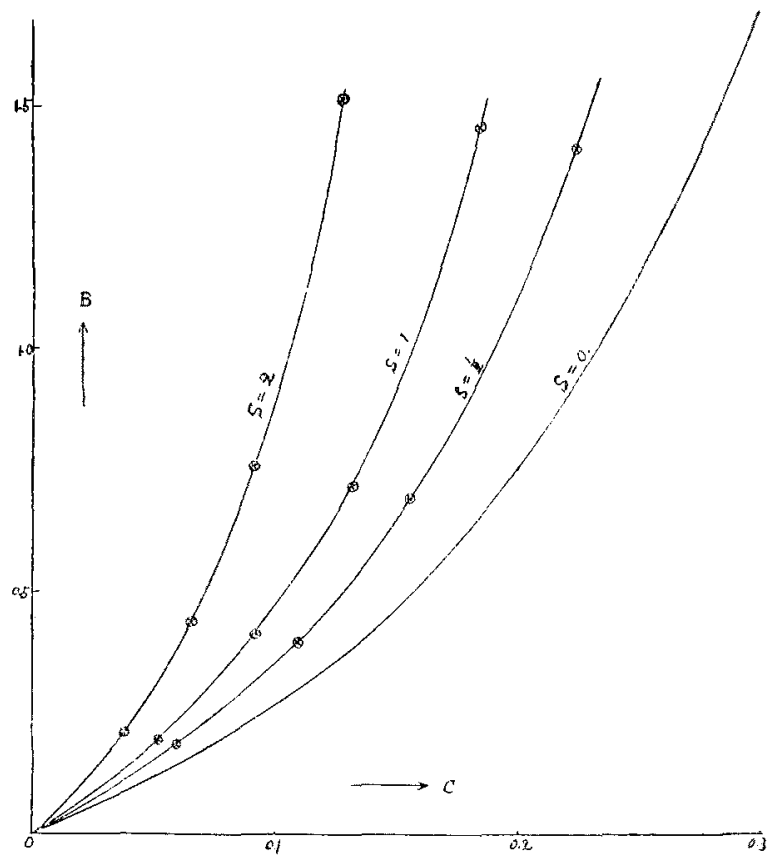

次の表は $\mathrm{NaCl}$ の場合を第 1 圖より、 $\mathrm{B}=1.0, \mathrm{~B}=0.7, \mathrm{~B}=0.4$ の三本の水平線に就 をて對數法則の適合些を检するため計算せるもの就り。

$$
\mathrm{B}=1.0
$$

s.

0

0.5

1.

2.

$\mathrm{B}=0.7$

$\mathrm{s}$

0

0.5

1.

2.
0

$$
\begin{gathered}
0.2320=\mathrm{C}_{0} \\
0.1905 \\
0.1570 \\
0.1060
\end{gathered}
$$

C

$$
0.1913=\mathrm{C}_{0}
$$

0.1560

0.1290

0.0870 $\log \mathrm{C}$

$\overline{1} .3655$

$\overline{1} .2799$

$\overline{1} .1959$

$\overline{1} .0253$

$\log \mathrm{C}$

$\overline{1} .2817$

$\overline{1} .1931$

$\overline{1} .1106 \mathrm{~s}$

$\overline{2} .9395$

$$
\log \mathrm{C}_{0}-\log \mathrm{C} \quad \frac{1}{\mathrm{~S}} \log \frac{\mathrm{C}_{1}}{\mathrm{C}}=\beta
$$

$\begin{array}{cc}- & - \\ 0.0856 & 0.1712 \\ 0.1696 & 0.1696 \\ 0.3402 & 0.1701\end{array}$

平均 $\beta=0.170$

0.0870

$$
\log C_{0}-\log C \quad \frac{1}{S} \log \frac{C_{y}}{C}=\beta
$$

0.0886

$0.177 \%$

0.1711

0.1711

0.8422

0.1711

平均 $\beta=0.172$ 
$\mathrm{B}=0.4$

$\begin{array}{ccccc}\mathrm{S} & \mathrm{C} & \log \mathrm{C} & \log \mathrm{C}_{0}-\log \mathrm{C} & \beta \\ 0 & 0.1345=\mathrm{C}_{0} & \overline{1} .1287 & - & - \\ 0.5 & 0.1100 & \overline{1} .0414 & 0.0873 & 0.1746 \\ 1 . & 0.0895 & \overline{2} 9518 & 0.1769 & 0.1769 \\ 2 . & 0.0612 & \overline{1} .7867 & 0.3420 & 0.1710\end{array}$

平均 $\beta=0.173$

之老見るに $\frac{1}{\mathrm{~S}} \log \frac{\mathrm{C}_{11}}{\mathrm{C}}=\beta$ は明に恒數となる。 meant取れるものなり。結局フェノール溶液に對する $\mathrm{NaCl}$ の作服としては $\beta=0.172$ なる在數を以て表はし得。

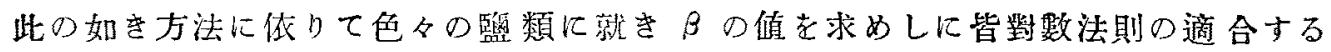
を知んり。而してßとしては次の如き值を得をり。

\begin{tabular}{|c|c|c|c|}
\hline 輿 & $\beta$ & 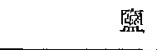 & $\beta$ \\
\hline $\mathrm{NaCl}$ & 0.172 & $\mathrm{LiBr}$ & 0.065 \\
\hline $\mathrm{NaBr}$ & 0.155 & $\mathrm{LiNO}_{3}$ & 0.088 \\
\hline NaNO & 0.113 & $\mathrm{Ca}\left(\mathrm{NO}_{3}\right)_{2}$ & 0.130 \\
\hline $\mathrm{Na}_{2} \mathrm{SO}_{4}$ & 0.420 & $\mathrm{Sr}\left(\mathrm{NO}_{3}\right)_{2}$ & 0.140 \\
\hline $\mathrm{ECl}$ & 0.133 & $\mathrm{SrCl}_{2}$ & 0.317 \\
\hline $\mathrm{KBr}$ & 0.111 & $\mathrm{BaCl}_{2}$ & 0.295 \\
\hline $\mathrm{KNO}_{3}$ & 0,130 & $\mathrm{Ba}\left\langle\mathrm{NO}_{3}\right\}_{2}$ & 0.145 \\
\hline $\mathrm{K}_{2} 8 \mathrm{O}_{4}$ & 0.300 & $\mathrm{MgSO}_{4}$ & 0.347 \\
\hline $\mathrm{LiCl}$ & 0.177 & & \\
\hline
\end{tabular}

以上余の幊驗は $25^{\circ} \mathrm{C}$ にて行ひし为のなるが、Philip よ Bramley [Journ. Chem.

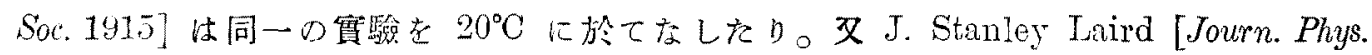

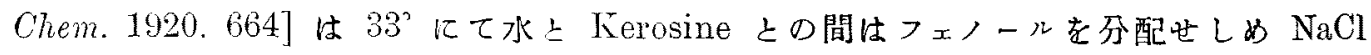
の影響を實䭸せるあり。此等の結果を計算するにやはり對數法則はあてはまり、及の 値恒數となる。即ち $\mathrm{NaCl} に$ 就きては、

$$
\begin{aligned}
& 20^{\circ} ; \quad \beta=0.154 . \\
& 33^{\circ} ; \quad \beta=0.177 .
\end{aligned}
$$

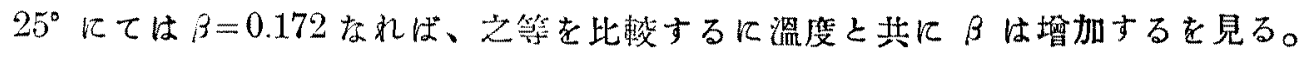

次に此の對數法則の熱力學的意味を考へん。

と索フェールの化學ポテンチャル (Chemical Potential) とし、Zを單位濃度に於 りる化學ポテンチャルとせば䟴度 Cに於ては 


$$
\zeta=Z+\mathrm{RT} \ln \mathrm{C} .
$$

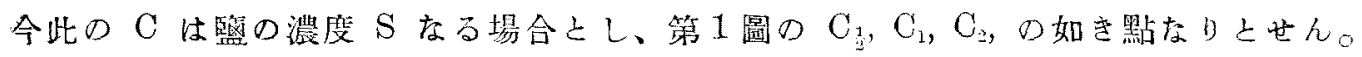
然らば、同一水平線上にある $\mathrm{C}_{0}$ 即ち電解物質の存在せざる場合には、

$$
\tau_{0}=Z_{0}+\mathrm{RT} \ln \mathrm{C}_{3}
$$

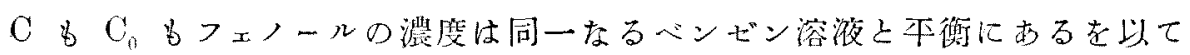

$$
\begin{gathered}
\zeta=\zeta_{0} \\
\therefore \quad Z-Z_{3}=\operatorname{RT}\left\{\ln \mathrm{C}_{3}-\ln \mathrm{C}\right\}=\operatorname{RT} \ln \frac{\mathrm{C}_{1}}{\mathrm{C}}
\end{gathered}
$$

となる。

然るに $\frac{1}{\mathrm{~S}} \log \frac{\mathrm{C}_{0}}{\mathrm{C}}=3$ は恒數なり。乙自然對數に直せば、

$$
\begin{gathered}
\frac{1}{\mathrm{~S}} \ln \frac{\mathrm{C}_{1}}{\mathrm{C}}=2.303 \beta \\
\therefore \quad Z-\mathrm{Z}_{0}=\mathrm{RT} 2.303 \text { 3.S. 即与 } \frac{Z-Z_{11}}{\mathrm{~S}}=\mathrm{RT} \cdot 2.303 \beta
\end{gathered}
$$

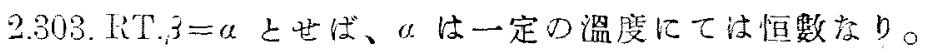

$$
\therefore \quad \frac{Z-Z_{3}}{S}=\text { 恒数 }=a
$$

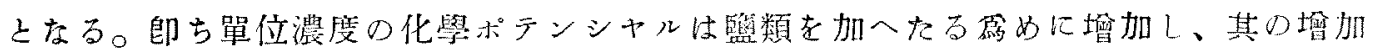
の量仗加入たる監の䇺度に比例す。

次第 1 圆の如を B-C 曲線の方程式を昶めん。

$$
\log \frac{\mathrm{C}_{0}}{\mathrm{C}}=\mathrm{S}_{i} 3 . \text { なれば } \quad \mathrm{C}_{13}=10^{\beta \mathrm{SS}} \mathrm{C} \text {. }
$$

之を前報又に於ける B.W 方程式

$$
\mathrm{B}=\mathrm{W}_{\gamma}+3 r^{3} \mathrm{KW}^{3} \quad \text { 的 } \mathrm{B}=2.272 \mathrm{C}_{10}+37.71 \mathrm{C}_{0}
$$

に代入すれば監類存在の場合には次の如き方程式を得。

$$
\mathrm{B}=2.272 \times 10^{\mathrm{BS} \mathrm{C}}+37.71 \times 10^{\mathrm{BS}} \mathrm{C}^{3}
$$

此の方程式は實灣值とよく一致す。其の一例として $\mathrm{NaNO}$ ，場合を第 2 圆に示 5。

第 2 圖は第 1 圖の如く $\mathrm{NaNO}_{3}$ を大㞦たる渡の $\mathrm{B}-\mathrm{C}$ 曲線を示せり。異る所は第 1 圖 
に於ては實驗值を連好たる曲線なり 第 2 圖 しが此の第 2 圖は方程式(1)よりの 理論的計算值を結べるものなり。圖

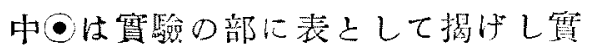
測值を示す。圖は理論と實際とが如 何によく一致世るるかをあらは世り。 此の如要一致は $\mathrm{NaNO}_{3}$ の場合の みなら方他の鹽類に就きても同樣な り。次に $\beta$ が各監類の作用を代表 する特性とすれば、此の及の值は 各イオンに就き加成性 (Additive Property）存る事は橓想世らるる所

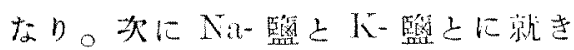

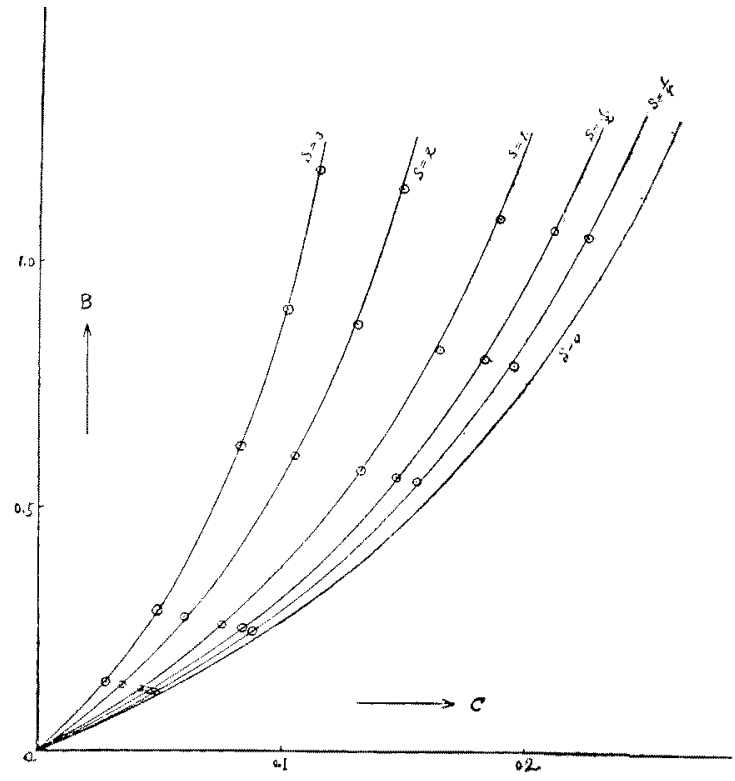
て示さん。次の表にてßは の中に示し、他の數字は其の差を示す。

\begin{tabular}{cccccccc}
\hline & $\mathrm{Cl}^{\prime}$ & $\left(\mathrm{Cl}^{\prime}-\mathrm{NO}_{3}^{\prime}\right)$ & $\mathrm{NO}$ & $\left(\mathrm{Br}^{\prime}-\mathrm{NO}_{3}^{\prime}\right)$ & $\mathrm{Br}^{\prime}$ & $\left({ }_{2}^{1} \mathrm{SO}^{\prime \prime}{ }_{4}-\mathrm{Br}^{\prime}\right)$ & ${ }_{3}^{1} \mathrm{SO}^{\prime \prime}$ \\
\hline $\mathrm{Na}$ & 0.172 & 0.059 & 0.113 & 0.042 & 0.155 & 0.055 & 0.210 \\
$(\mathrm{Na}-\mathrm{K})$ & 0.039 & & 0.083 & & 0.044 & & 0.030 \\
$\mathrm{~K}$ & 0.133 & 0.058 & 0.1150 & 0.031 & 0.111 & 0.069 & 0.130 \\
\hline
\end{tabular}

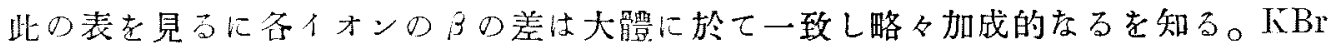
のßの值の少しく小に過ぐるは恐らく實驗の誤差に依るものならん。 ナトリゥム及びカリゥム以外の監類に就ては加成性を發見せず。

摘 要

水とベンビンとの間に於けるフェノールの分配に對する中性監類の影響に就きて實 測し其の所調暨析作用を砸究せり。

フェノールに對する監析作用に於て泣對數法則の適合するを知れり。師ち監類を加 ふる事に依つてフェノールの單位滛度の化學ポテンシャルは增加し此の增加の量は加

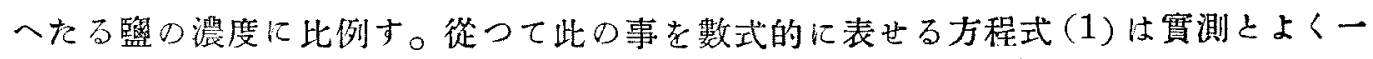




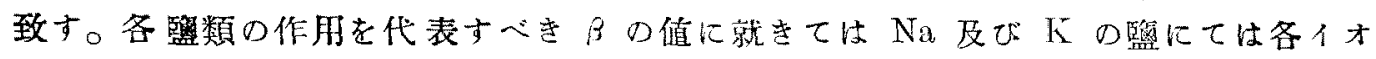
ンの加成性なるを見る。

以上の研究は恩師池田菊苗博士の御懇切なる御指導に基く子のにして此所に深く感 謝す。 東京帝國大學、理學部、化學敎空に於て。

\section{寒天ヒドロゾルの膠化の電解質電氭傳導度に及ほす影響}

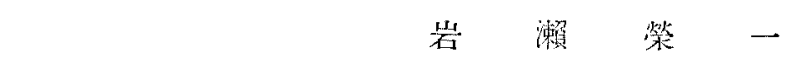

\section{(一) 緒 言}

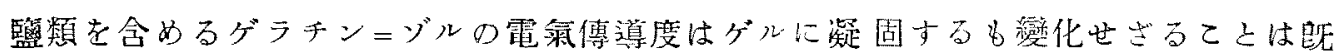
に Arrheniusにより古く報告せられたり。(Frendlich. Kapillarchemie 975 (192:3) 參 照; Arrhenius. Oefver's Stockholm Akad. 6, 121 (1887))。更に I[cBain 及び M. E.

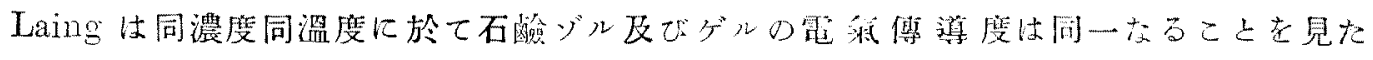
b。(M. E. Laing \& J. W. McBain. Trans. Chem. Soc. 117, 1506 (1920); M. E. Laing \&J. W. McBain. Ber. 48, 938 (1915))。然るに E. Hatschek 及t: T. H. Humphry の 發表に上れ代石酸は禁牀電解質 (colloidal electrolyte) なる特殊の場合にして、それ自

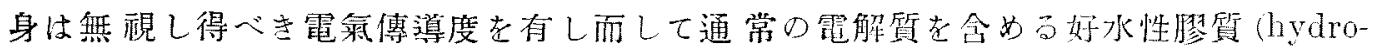
phile colloid)上は多少異れる所あるものにして硫酸銅を含める寒天はゾルーダル轉移

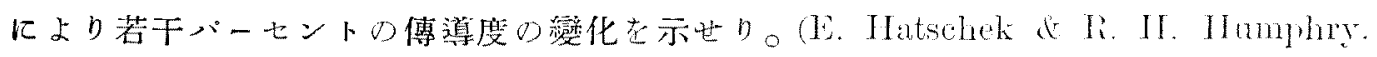
Trans. Faraday Soc. 20, 18 (1924))。著者は此の現芜を更に確め數種の監類の買りたる

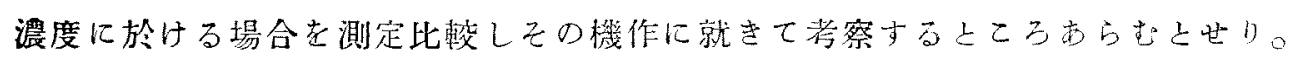

\section{(二）寒天ヒドロゾルの製法}

擦合せにて逆流冷却器と連古容量 $200 \mathrm{cc}$. の丸底フラスコに0.万 $\mathrm{g}$. の粉狀寒天及び

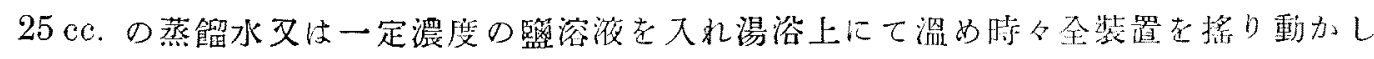
て内容物の混合を試み均一に寒天の分政する如くなし液の透明上なるまで加熱を縜け

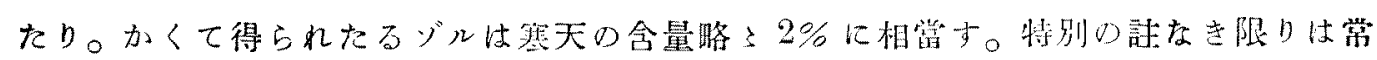
几斯の如き割合几て分散せしぬたるるのなり。秤量の便宜上寒天は Merck 製の細粉 狀のものを其傈使用せり。

\section{（三）贒驗㜪置及び測定の方法}

通常の如くホ平ートストン橋の方法により交流を用ひ受話器を以てその最小音の䇢 